The Council announced that the following grants to the University had been made: (1) $£ 10,000$ over a period of ten years by the Nuffield Trust to establish a readership or senior lectureship in the Dental School for the purpose of encouraging research into problems of dental health. (2) An annual grant of $£ 600$ for seven years from Messrs. Turner and Newall for the institution of a research fellowship to promote research in engineering, chemistry, physics, textile industries or any allied science approved by the donors. (3) $£ 1,500$ a year for two years from the Bradford Dyers' Association, Ltd., for the institution of two research fellowships: one in dyeing in the Department of Colour Chemistry and Dyeing; and one in Textile Finishing in the Department of Textile Industries; together with a grant of $£ 400$ to each of the two Departments for the maintenance and replenishment of their resources; (4) $£ 300$ a year from the International Wool Secretariat for the establishment of a Wool Research Scholarship. (5) 6,500 dollars from the Rockefeller Foundation for the purchase of equipment in the United States required in connexion with Prof. Astbury's researches on the analysis of biological tissues, in support of which the Foundation has made a grant of $£ 2,140$ a year during the past twelve years. (6) An annual grant of $£ 100$ from Williams (Hounslow), Ltd., for equipment for the proposed new lectureship on lakes and pigments in the Colour Chemistry and Dyeing Department. (7) $£ 750$ from Messrs. Babcock and Wilcox, Ltd., for equipment to be used in the Coal Gas and Fuel Industries Department in the training of fuel technologists.

\section{German University in Prague}

IT is announced by The Times correspondent in Prague that, by a presidential decree dated October 18 , the German University in Prague and the German technical colleges at Prague and Brno will cease to exist on November 17, the day on which the country commemorates the shooting of Czech students and the closing of Czechoslovak universities by the Germans in 1939.

\section{Ministry of Labour and National Service : Technical and Scientific Register}

DeMoBILIZED men and returned prisoners of war who are scientific workers, professional engineers, architects or surveyors, are invited by the Ministry of Labour and National Service to make use of the service provided by the Technical and Scientific Register of the Appointments Department of the Ministry, at York House, Kingsway, London, W.C.2 (Telephone: Temple Bar 8020). A technical staff, competent to give advice and assistance, has been augmented to meet problems of settlement and reconstruction. A large variety of vacancies, both at home and overseas, is now available for fully qualified men of science, engineers, etc. Inquirers are particularly asked to write or telephone for appointments, stating occupation, qualifications, and the purpose of the proposed visit.

\section{Fiftieth Anniversary of the Discovery of X-Rays}

To commemorate the discovery by Röntgen of $\mathrm{X}$-rays on November 8, 1895 , a series of meetings has been planned by the Royal Society, Royal Society of Medicine, Royal Photographic Society, Physical Society, Institute of Physics, Institution of Electrical Engineers, British Institute of
Radiology, and Society of Radiographers acting together. On November 8, inaugural meetings will be held at the Royal Society and the Royal Society of Medicine, at which Sir Henry Dale and Lord Horder respectively will preside. During the morning of November 9 papers on "Applications of X-Rays to Physics and Chemistry" will be read at the Royal Institution, and there will be a meeting at the Royal Society of Medicine for lectures on "Diagnostic Radiology" and "Radio-Therapy". During the afternoon, at the Central Hall, Westminster, a joint meeting of the participating societies will be held at which Sir Lawrence Bragg will speak on "The Scientific Consequences of Röntgen's Discovery of X-Rays". During the morning of November 10, papers will be read at the Royal Institution on "Applications of X-Rays to Physics and Chemistry". The remainder of the day will be occupied with meetings at the Institution of Electrical Engineers: the Society of Radiographers will hold a medical meeting, and later there will be two general sessions to hear historical reviews covering X-ray equipment, X-ray photographic materials and industrial $\mathrm{X}$-ray analysis.

\section{The Night Sky in November}

NEw moon occurs on Nov. 4 d. $23 \mathrm{~h} .11 \mathrm{~m}$. U.T., and full moon on Nov. 19d. 15h. 13m. The following conjunctions with the moon take place: Nov. 2d. 12h., Jupiter $4^{\circ}$ S. ; Nov. 2d. $20 \mathrm{~h}$., Venus $4^{\circ} \mathrm{S}$.; Nov. 6d. 17h., Mercury $5^{\circ}$ S.; Nov. 23d. 13h., Saturn $2^{\circ} \mathrm{S} . ;$ Nov. 24d. 03h., Mars $0 \cdot 6^{\circ} \mathrm{S} . ;$ Nov. 30d. 05h., Jupiter $4^{\circ} \mathrm{S}$. Occultations of stars not fainter than magnitude 6 are as follows: Nov. 15d. 19h. $33 \cdot 9 \mathrm{~m}$, 24 B. Ceti $(D)$; Nov. 2ld. $22 \mathrm{~h}$. $05 \cdot 7 \mathrm{~m} ., 3$ Gemi. $m(R)$; Nov. 22 d. $5 \mathrm{~h} .53 \cdot 5 \mathrm{~m} ., 36 \mathrm{~B}$. Gemi. $(R)$; Nov. 28d. 1h. $58 \cdot 3$ m., $\nu$ Virg. $(R)$; $D$ and $R$ refer to disappearance and reappearance, respectively, and the times refer to Greenwich. Mercury is unfavourably placed for observation, setting about half an hour after the sun during the month. Venus is conspicuous as a morning star, rising at $4 \mathrm{~h} .44 \mathrm{~m} ., 5 \mathrm{~h} .30 \mathrm{~m}$. and $6 \mathrm{~h} .19 \mathrm{~m}$. at the beginning, middle and end of the month, respectively. Mars, in the constellation of Cancer, can be seen in the late evening hours, rising at $21 \mathrm{~h}$. $13 \mathrm{~m}$., and $19 \mathrm{~h} .49 \mathrm{~m}$. at the beginning and end of the month. Jupiter, in the constellation of Virgo, is visible in the morning hours. The planet rises at $4 \mathrm{~h} .37 \mathrm{~m}$. on Nov. 1 and at $3 \mathrm{~h} .14 \mathrm{~m}$. on Nov. 30. Saturn, in the constellation of Gemini, rises about the same time as Mars at the beginning of the month and at $19 \mathrm{~h} .16 \mathrm{~m}$. at the end of the month. The planet is stationary on Nov. 6. The Leonid meteors are due on Nov. 13-14 and the Andromedids about Nov. 2027 , but both these showers have been very feeble, or in some cases practically non-existent, for a number of years.

\section{Announcements}

Srr John Boyd ORR, M.P., has been elected rector of the University of Glasgow.

Captain Arthur Dyoe Duckworth, R.N., has been appointed secretary of the Institution of Naval Architects in succession to the late Mr. G. V. Boys, and will shortly take up his duties at the Institution.

The Conference in Prague on the use of X-ray methods in the metal industry (see Nature of October 20 , p. 473) has been postponed and will take place during November 28-December 1. 